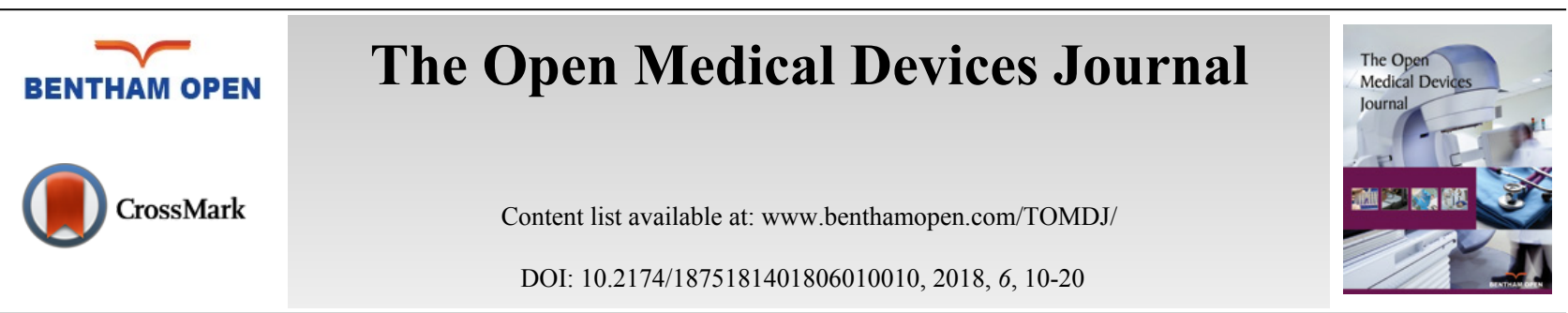

REVIEW ARTICLE

\title{
Hospital Engineering of Medical Devices in France
}

\author{
Mohamed Moumaris $^{1,2, *}$, Jean-Michel Bretagne ${ }^{1}$ and Nisen Abuaf ${ }^{2,3}$ \\ ${ }^{I}$ Direction des équipements, Hôtel-Dieu, Groupe Hospitalier Universitaire Paris Centre, Département des \\ Investissements, AP-HP - 1 Place du Parvis Notre Dame, 75004 Paris, France \\ ${ }^{2}$ Laboratoire d'Hématologie et d'Immunologie, Hôpital Tenon, Groupe Hospitalier Universitaire Paris Est, AP-HP et \\ Département d'Immunologie, Université Pierre et Marie Curie - 4 Rue de la Chine-75020 Paris, France \\ ${ }^{3}$ Service de Dermatologie et d'Allergie, Hôpital Tenon, Groupe Hospitalier Universitaire Paris Est, AP-HP et \\ Université Pierre et Marie Curie, 4 Rue de la Chine, 75020 Paris, France
}

\begin{abstract}
Biomedical engineering handles the organization and functioning of medical devices in the hospital. This is a strategic function of the hospital for its balance, development, and growth. This is a major focus in internal and external reports of the hospital. It's based on piloting of medical devices needs and the procedures of biomedical teams' intervention. Multi-year projects of capital and operating expenditure in medical devices are planned as coherently as possible with the hospital's financial budgets. An information system is an essential tool for monitoring medical devices engineering and relationship with medical services.
\end{abstract}

Keywords: Medical device, Hospital, Capital, Investment, Operational, Expenditure.

\section{INTRODUCTION}

Biomedical engineering is a discipline with its own methods of analysis and thinking. Guides to good practice formalize biomedical function $[1,2]$. The biomedical engineering plays a crucial role in the strategic competitiveness of the hospital and affects its performance and capital. It evolves with technological progress and national policies. It plans funding of all expenditures during the lifecycle of medical devices [3 - 5]. The realization of biomedical engineering is based on financial, material and human resources. Material resources are constituted by the provision of spacious premises, maintenance tools, spare parts, procedures of interventions and maintenance process. Human resources are based on the engineers to supervise staff, assign maintenance tasks and coordinate service orders. The engineers enhance workstation and ensure the relationship with external providers. The biomedical engineering budgets acquisition of medical devices at the lowest cost and returns on investment, it develops a purchasing policy to reduce operating spending of obsolete equipment and it homogenizes the biomedical park to negotiate discounts with suppliers. The biomedical engineering programs maintenance procedures of medical devices failures, it manages schedules of service orders and monitors maintenance contracts [6 - 8]. Various mechanisms are used to make profitable biomedical engineering. The ISO standards support to a better use of resources. The regulatory obligation is the pillars of biomedical engineering. The information system is essential for the automation of interventions and managing acquisitions [9 - 19]. How biomedical engineering of medical devices leads these resources?

\section{CENSUS AND ASSESSMENT OF BIOMEDICAL PARK NEEDS}

Medical devices consist of a device intended for diagnosis, control, and treatment of disease. There are various types of medical devices such as devices for imaging, devices for laboratory, and devices for medicine or surgery (Table 1). The inventory is the basis of engineering of medical devices; it provides all the information to ensure their

* Address correspondence to this author at the Direction des équipements, Hôtel-Dieu, Groupe Hospitalier Universitaire Paris Centre, Département des Investissements, AP-HP - 1 Place du Parvis Notre Dame, 75004 Paris, France; Tel: 0033762122825; E-mail: mohamed.moumaris@orange.fr 
effectiveness. The data included in the inventory provide information about the function, risk, criticality, and utilization of the medical device. These criteria provide a system for measuring the performance of the biomedical park. The inventory reflects the state of medical devices in the hospital. All the information related to each device is included in this inventory and it is the instrument of budgeting and piloting of maintenance (Table 2). The Computerized Maintenance Management System (CMMS) traces all the order of maintenance of the medical device. The list of operating devices updates regularly in the CMMS mentioning at least the brand and the lifetime of medical devices. The criticality and utilization rate of medical devices can be used as a basis for the elaboration of the reform policy [20 - 22].

Table 1. Biomedical park.

\begin{tabular}{|c|c|}
\hline Speciality & Medical Devices \\
\hline $\begin{array}{l}\text { Medicine or } \\
\text { Surgery }\end{array}$ & $\begin{array}{c}\text { endoscopy, bistoury, operating microscope, surgical robot, dental surgery unit, operating table, ophtalmoscope, monitors, bay } \\
\text { catheterization, ECG, electroencephalography, hemodialysis generator, radiotherapy, particle accelerator, cyclotron, anesthesia } \\
\text { workstation, defibrillator, pump, ventilator }\end{array}$ \\
\hline Imaging & thermography, scanner, radiography, radioscopy, magnetic resonance imaging, echography, osteodensitometry, scintigraphy \\
\hline Laboratory & $\begin{array}{l}\text { analyzer, automaton, DNA apparatus, flow cytometry, microtomes, apparatus inclusion tissue, plasmafilter, cell separator, } \\
\text { chromatograph, mass spectrofluorimeter, spectrometer, microcope, centrifuge }\end{array}$ \\
\hline
\end{tabular}

Table 2. State of biomedical park.

\begin{tabular}{|c|c|}
\hline Criteria & Description \\
\hline Inventory number & Unique identification number assigned by the hospital to a medical device \\
\hline CNEH code & Code of the national centre of hospital expertise \\
\hline CMP & Public market code \\
\hline Designation & Description of medical device, particularly its function \\
\hline Brand & Distinctive sign assigned by the manufacturer of medical device \\
\hline Model & Unique reference assigned by the manufacturer of medical device, it is an aesthetic creation \\
\hline Type & Characteristics assigned to model category of medical device \\
\hline Serial number & Unique identification number assigned by the manufacturer to a medical device in a series \\
\hline Supplier & Provider which ensures maintenance and warranty of medical device \\
\hline Warranty & Free insurance contract in a given period to validate the success of medical device commissioning \\
\hline After sale service & Service of a company, ensuring the commissioning and maintenance of medical device acquired \\
\hline Corps profession & Corporation of persons practicing the same profession and subject to the same regulations \\
\hline Geographical location & Coordinates of the localion of the medical device for maintenance and replacement \\
\hline Service & Group of hospital units \\
\hline Pole & Group of hospital services \\
\hline Cost center & Entity of the hospital \\
\hline CE marking class & Risk assessment certification and prioritization criteria for maintenance of medical devices \\
\hline Lifetime & Duration of activity in which the medical device is functional \\
\hline Date of commissioning & Helps to determine depreciation and seniority \\
\hline Cost of purchase & Used to determine the value of biomedical park \\
\hline Status & Used to determine if the medical device is in property, on loan, in evaluation, in hiring... \\
\hline Criticity & Used to classify medical devices by estimating their risk \\
\hline Antiquated & $\begin{array}{c}\text { It is } 0 \text { if the medical device is new, it is } 1 \text { if the medical device has reached its lifetime, it is greater than } 1 \text { if the medical } \\
\text { device has exceeded its lifetime }\end{array}$ \\
\hline Amortization period & Normal duration of use of the medical device \\
\hline
\end{tabular}

Criticity $=$ Probability of occurrence of risk $\times$ Gravity of the effect of risk

\section{Antiquated $=$ Age $\times$ Lifetime}

Biomedical engineering is based on the identification of financial, technical and human resources needs. In France Hospital of Medicine, Surgery, and Obstetrics (Hospital MSO) based on an efficient technical platform, offer various care for the treatment of most diseases at all ages, responding to the health needs of the population. The number and nature of acts and stays determine the provisional statement of recipes and expenditure "pricing activity (T2A)". The activity determines the annual hospital resources and budget to finance investment and exploitation of medical devices 
(Table 3). The amount of the operating budget is estimated in the budget accounts for each pole. There are the budget accounts for the external servicing and maintenance underinclusive or attachment market. The type of inclusive or attachment market depends on the medical device. There are budgetary accounts spare parts supplies for internal servicing and maintenance. The amount of the operating budget is estimated at the poles for each budget account. There is the imaging pole, biology pole and medical specialty pole. Every pole consists of a set of the cost center. The amount of pole budget is the sum of cost centers budgets. The amount of the hospital's operating budget is the sum of the budget by budget accounts or by pole (Table 4). The values shown in Tables $\mathbf{3}$ and $\mathbf{4}$ are estimates based on our hospital experience in engineering of medical devices. The traceability of maintenance performed on medical devices plays a major role in determining the needs necessary for operating $[23,24]$.

Table 3. Resources of biomedical management.

\begin{tabular}{|c|c|}
\hline \multicolumn{2}{|c|}{ Indicators } \\
\hline Number of hospitalization in medicine, surgery and obstetrics \\
\hline Number of medical staff & 8100 \\
\hline Number of nonmedical staff & 100 \\
\hline Number of hospitalization beds & 500 \\
\hline Number of medical devices & 3000 \\
\hline Investment endowments of medical devices & $4000000,00 €$ \\
\hline Functioning endowments of medical devices & $1613934,00 €$ \\
\hline
\end{tabular}

Table 4. Provisional operating plan of medical devices.

\begin{tabular}{|c|c|c|c|c|c|c|c|c|}
\hline & \multicolumn{3}{|c|}{ Account Maintenance in Attachment } & \multicolumn{3}{|c|}{ Account Inclusive Maintenance } & \multirow{2}{*}{$\begin{array}{c}\begin{array}{c}\text { Account Spare } \\
\text { Parts }\end{array} \\
7 \\
\end{array}$} & \multirow{2}{*}{ Total Amount } \\
\hline & 1 & 2 & 3 & 4 & 5 & 6 & & \\
\hline Biology cost centers & \multicolumn{8}{|c|}{ Anatomo-Pathology, Hematology, Parasitology, Microbiology, Virology, Biochemistry } \\
\hline $\begin{array}{l}\text { Total amount for biology } \\
\text { pole }\end{array}$ & $0,00 €$ & $103142,00 €$ & $72582,00 €$ & $0,00 €$ & $129883,00 €$ & $22921,00 €$ & $53481,00 €$ & $382009,00 €$ \\
\hline Imaging cost centers & \multicolumn{8}{|c|}{ Radiology, Magnetic Resonance Imaging, Scanner } \\
\hline $\begin{array}{l}\text { Total amount for imaging } \\
\text { pole }\end{array}$ & $12725,00 €$ & $0,00 €$ & $19088,00 €$ & $591724,00 €$ & $0,00 €$ & $0,00 €$ & $12725,00 €$ & $636262,00 €$ \\
\hline $\begin{array}{l}\text { Medical specialty cost } \\
\text { centers }\end{array}$ & \multicolumn{8}{|c|}{ Anesthesia, Nephrology, Hepato-Gastero-Enterology, Oto-Rhino-Laryngology, Orthopaedic, Surgery } \\
\hline $\begin{array}{l}\text { Total amount for the medical } \\
\text { specialty pole }\end{array}$ & $11795,00 €$ & $5898,00 €$ & $300780,00 €$ & $41284,00 €$ & $0,00 €$ & $129748,00 €$ & $106158,00 €$ & $595663,00 €$ \\
\hline Total & $24520,00 €$ & $109040,00 €$ & $392450,00 €$ & $633008,00 €$ & $129883,00 €$ & $152669,00 €$ & $172364,00 €$ & $1613934,00 €$ \\
\hline
\end{tabular}

1: servicing and repair of imaging devices - 2: servicing and repair of laboratory devices - 3: servicing and repair of medical specialty devices - 4: maintenance of imaging devices - 5: maintenance of laboratory devices - 6: maintenance of medical specialty devices - 7: spare parts supplies.

Medical devices creative needs are identified when disease care generates activities in a number of acts and duration of the examination. The number of medical devices is calculated in relation to the number of beds. Medical devices renewal needs are identified when there is an inadequacy at hospital's needs. The choice of medical device replacement is considered in relation to the frequency of breakdowns and the antiquated. Medical devices modernization needs are considered to track technological developments and updating performance.

The cost is estimated for each medical device. The amount of the investment budget is estimated for biology pole, imaging pole and medical specialty pole. Every pole consists of a set cost center. The amount of budget pole is the sum of cost centers budgets. The amount of the hospital's investment budget is the sum of the budgets for each pole. The census of medical devices requirements and translating them into investment plan are done on the basis of the function, utility, and commissioning of the medical devices. The decision to launch an investment for a medical device among several requirements is based on multi-criteria prioritization formulas. Priority rules are the criteria of weight and incidence of functioning (staff, consumables cost, maintenance cost) then of investments (construction and infrastructure works, computing). The values shown in Table $\mathbf{5}$ are estimates based on our hospital experience in engineering of medical devices (Table 5). 
Table 5. Provisional investment plan of medical devices.

\begin{tabular}{|c|c|c|c|c|c|c|c|c|c|c|c|}
\hline \multirow{2}{*}{ Pole } & \multirow{2}{*}{$\begin{array}{l}\text { Designation } \\
\text { of Device }\end{array}$} & \multirow{2}{*}{$\begin{array}{c}\text { Date of } \\
\text { Commissioning }\end{array}$} & \multirow{2}{*}{ Need } & \multirow{2}{*}{$\begin{array}{l}\text { Unit } \\
\text { Price }\end{array}$} & \multirow{2}{*}{$\begin{array}{l}\text { Total } \\
\text { Cost }\end{array}$} & \multicolumn{3}{|c|}{ Incidence Functioning } & \multicolumn{2}{|c|}{$\begin{array}{c}\text { Incidence } \\
\text { Investments }\end{array}$} & \multirow[b]{2}{*}{ Priorities } \\
\hline & & & & & & Staff & $\begin{array}{c}\text { Consumables } \\
\text { Cost }\end{array}$ & $\begin{array}{c}\text { Maintenance } \\
\text { Cost }\end{array}$ & Works & Computing & \\
\hline $\begin{array}{l}\text { Biology } \\
\text { cost } \\
\text { centers }\end{array}$ & \multicolumn{11}{|c|}{ Anatomo-Pathology, Hematology, Parasitology, Microbiology, Virology, Biochemistry, Pharmacy } \\
\hline $\begin{array}{l}\text { Biology } \\
\text { pole }\end{array}$ & $\begin{array}{l}\text { Biological } \\
\text { function }\end{array}$ & $\begin{array}{c}\text { Duration of } \\
\text { biological } \\
\text { activity }\end{array}$ & $\begin{array}{l}\text {...Renewal, } \\
\text { Creation... }\end{array}$ & $\begin{array}{c}\text { Cost of } \\
\text { each } \\
\text { biology } \\
\text { device }\end{array}$ & $\begin{array}{c}600 \\
000,00 \\
€\end{array}$ & $\begin{array}{l}\ldots . . \text { Yes, } \\
\text { No... }\end{array}$ & ...Yes, No... & ...Yes, No... & $\begin{array}{c}\ldots . \text { Yes, } \\
\text { No... }\end{array}$ & ...Yes, No... & 1 to $x$ \\
\hline $\begin{array}{c}\text { Imaging } \\
\text { cost } \\
\text { centers }\end{array}$ & \multicolumn{11}{|c|}{ Radiology, Magnetic Resonance Imaging, Scanner } \\
\hline $\begin{array}{l}\text { Imaging } \\
\text { pole }\end{array}$ & $\begin{array}{l}\text { Imaging } \\
\text { function }\end{array}$ & $\begin{array}{c}\text { Duration of } \\
\text { imaging activity }\end{array}$ & $\begin{array}{l}\text {...Renewal, } \\
\text { Creation... }\end{array}$ & $\begin{array}{c}\text { Cost of } \\
\text { each } \\
\text { imaging } \\
\text { device }\end{array}$ & $\begin{array}{c}1200 \\
000,00 \\
€\end{array}$ & $\begin{array}{l}\ldots . . \text { Yes, } \\
\text { No... }\end{array}$ & ...Yes, No... & ...Yes, No... & $\begin{array}{l}\ldots . \text { Yes, } \\
\text { No... }\end{array}$ & $\ldots Y$ es, No... & 1 to $x$ \\
\hline $\begin{array}{l}\text { Medical } \\
\text { specialty } \\
\text { cost } \\
\text { centers }\end{array}$ & \multicolumn{11}{|c|}{$\begin{array}{c}\text { Anesthesia, Nephrology, Hepato-Gastero-Enterology, Oto-Rhino-Laryngology, Dermatology, Functional Exploration, Orthopaedic, } \\
\text { Surgery }\end{array}$} \\
\hline $\begin{array}{c}\text { Medical } \\
\text { specialty } \\
\text { pole }\end{array}$ & $\begin{array}{l}\text { Medical } \\
\text { specialty } \\
\text { function }\end{array}$ & $\begin{array}{c}\text { Duration of } \\
\text { specialty activity }\end{array}$ & $\begin{array}{l}\text {...Renewal, } \\
\text { Creation... }\end{array}$ & $\begin{array}{c}\text { Cost of } \\
\text { each } \\
\text { medical } \\
\text { specialty } \\
\text { device }\end{array}$ & $\begin{array}{c}2200 \\
000,00 \\
€\end{array}$ & $\begin{array}{l}\ldots . . Y \text { Yes, } \\
\text { No... }\end{array}$ & ...Yes, No... & ...Yes, No... & $\begin{array}{l}\ldots \text {..Yes, } \\
\text { No... }\end{array}$ & ...Yes, No... & 1 to $\mathrm{x}$ \\
\hline $\begin{array}{c}\text { Cost of all } \\
\text { medical } \\
\text { devices of } \\
\text { hospital }\end{array}$ & \multicolumn{11}{|c|}{$4000000,00 €$} \\
\hline
\end{tabular}

$$
\text { Priority }=\frac{\sum_{i=1}^{i=n} \text { Weight } \times \text { Incidence }}{\sum_{i=1}^{i=n} \text { Weight }}
$$

The needs assessment depends on national and regional policies which fix the resources. Several elements are considered to assess the needs: i) the state of biomedical park ii) the medical proposal and the expertise of the manufacturer iii) the health status of the population iv) the operating and investment incidence v) the impact of technology on the human resources and skills required. In agreement with the medical department heads and biomedical engineer, the satisfaction of needs is done according to the program of the hospital with respect to its budgetary [25].

\section{PILOTING THE INVESTMENT AND OPERATING OF MEDICAL DEVICES}

National and regional health policies are the source of budgetary endowments of the hospital. Hospital recipes are defined by pricing the T2A activity, T2A is the mode of financing of the medical, surgical and obstetric activities of the public and private hospital, in which the resources are calculated on the basis of acts and stays. The number of admission and hospitalization reflect the hospital activity. Hospital activity and resources are measured by the Medicalization of Information Systems Programs (PMSI), PMSI classifies the stay of each patient in the homogeneous Group of Patients (GHM) and the Homogeneous Groups of Stay (GHS) in which prices of the activities are fixed. With T2A, it is the activity produced that allows the estimation of the provisional statement of recipes and expenditure of hospitals under the control of the regional health agency and the regional chamber of accounts. The regional schematics of health organization are defined relative to demographic parameters and clinical needs of the population. The diseases treated and major medical specialties express the orientations of the hospital. The regional health agency elaborates investment envelopes hospitals and defined the policy of budget allocations according to the multi-year contract of objectives and means. Approximately $15 \%$ of the hospital budget is dedicated to medications and medical devices. The 
acquisitions and an operating budget of medical devices consist of basic endowments, negotiated complementary endowments, endowments for technological innovations, heavy equipment endowments, and strategic operations endowments. The provisional budget allocation of resources is elaborated through analysis of annual expenditures and needs. The directors' board defines biomedical policy in relation to the state of receipts and expenditure forecasts, and contracts with pole leaders [26 - 28].

Investment and maintenance policies depend, for the most part, on the amount and type of inventoried medical devices. Depending on the budget allocated by the directors' board of the hospital, the biomedical engineer pilots financial, material and human resources, to program acquisitions and biomedical maintenance. The resources are fixed and limited which leads to prioritize identified needs, and then give priority to primary care activities. The medical devices are classified according to their classification code, the cost center, their usefulness and technological level. Biomedical engineer adapted the needs with the budget allocated through prioritization criteria. The strategic criteria weighed in the ranking of the hospital. Technological criteria symbolize the innovation, reducing the antiquated of the biomedical park, and commercial failure. Health criteria represent the target population of the medical devices. The financial criteria favor reducing costs of acquisition and operating. Resource optimization models are used to reduce investment and operating expenses of medical devices [29 - 31].

The investment policy is based on prioritization model, the decision to acquire medical devices consists in identifying investment criteria such as the lifetime, function and utility of medical devices, then to determine the value of decision function on the basis of criteria as weight and incidence of functioning then of investments. The maintenance policy is based on the maintenance prioritization criteria for medical devices such as risk and criticality. Biomedical engineer formalizes and translates the needs into feasibility study then on investment and maintenance program, according to an implementation schedule of the overall project (Tables $\mathbf{4}$ and $\mathbf{5}$ ).

The directorate in agreement with the medical board and the commission of medical devices analyzes the needs according to the antiquated, criticality and utility. He also confirms the provisional plan of medical devices. The financial capacity determines investment choices of medical devices. Endowments of investment are often favored on maintenance endowments. The ratio of maintenance cost should vary from $4 \%$ to $10 \%$ of the value of the biomedical park. Currently, for a 500-beds hospital with 3000 medical devices, the value of biomedical park is about $38000000 €$. For a biomedical park in a 500-beds hospital to be profitable the maintenance spending represents approximately $1613934 €$ per year and the financial acquisition program of medical devices is estimated on average at $4000000 €$ per year (Table 4 and 5) [32 - 34].

Biomedical engineer implements an action plan using tools such as Gantt chart; ensures a relay between industry and medical actors, leads procedures related to the public market to buy technologically challenging medical devices at the lowest price. The acquisition of medical devices and external service orders are made on the basis of market contracts or direct command. The realization of market contracts is proceeding through the elaboration of the specifications and consultations. The expertise of industry offerings is formalized by the report of the technical choices of the performances. Evaluation of medical devices depends on financial, environmental, socioeconomic and medical aspects. Negotiation procedures with suppliers are often essential. The implementation of the planned projects is done by the commitment authorizations of payment credit, purchase orders and payment made to liquidate the bills.

Biomedical engineer handles delivery and installation of the medical devices purchased, ensures commissioning and adequate functioning of medical devices, checks the performance claimed by the supplier during all the life cycle of medical devices, checks compliance of the guarantee contract, pilots maintenance interventions, measures the operating costs, provides staff training and supports availability of medical devices. Endowments allocated to human resources and technical resources determine the choice of the feasibility of maintenance internally by the biomedical department or externally by service providers. For heavy medical devices outsourcing is the rule, as the eventual existence of a market contract. External maintenance is provided through the guarantee contract, a flat-rate contract or an attachment contract. The shared contract is often favored because it perpetuates the know-how then reduces hourly costs and intervention deadlines. The technical staff training is carried out through learning by the manufacturer. Programming maintenance is affected by priority according to the assignments of the hospital, the regulatory obligation and the criticality of medical devices [35 - 40].

Biomedical policy involves spending analysis to make savings, costing of interventions and spare parts, then monitoring of warranty and maintenance contracts. Maintenance interventions are spread relative to the number and categories of medical devices. The ratios of spending operate by account number, supplier and cost center. The majority 
of the budget is spent on medical specialty pole with numerous medical devices (syringe pump, monitors...) and on imaging pole with heavy medical devices (MRI, scanner). They are in their majority under maintenance contracts, the expensive cost of these external maintenance includes workforce, spare parts, and displacement. The rest of the budget is devoted to internal maintenance for the purchase of spare parts, software and maintenance tools (Table 5).

The medical devices are assessed by key indicators such as the rate of failure and technical interventions. It is judicious to compare maintenance costs of the same type devices from different manufacturers. The maintenance engineering uses organizing methods such as just-in-time and total quality approach. The total productive maintenance program is used to improve the maintenance function, reduce costs and maximize the device's efficiency. Engineering of biomedical park uses profitable strategies such as the free availability of medical devices in exchange for purchasing consumables [41 - 43].

\section{DASHBOARDS}

Indicators are tools for measuring performance and decision support. The dashboard is a set of indicators enabling evaluation of the organization and optimization of hospitals' resources. The financial indicators are mainly financial information by cost center and budget account, the physical indicators are information on the process involving various actors and different types of hospital services. The dashboard analyzes the achievement of strategic objectives and pilots operational activities in terms of care offer. The information system collects, processes, and produces dashboard information. The PMSI produces cost information per pathology and/or per patient [44 - 50].

The information system is an essential tool to analyze needs and monitor the implementation of the biomedical program within the hospital. This is a database accessible to various stakeholders. It allows sharing the plane of medical devices, maintenance recommendations, regulatory texts, guides to good biomedical practices and ISO standards [51]. The information system manages committed budgets, monitors operations, and processes orders. It follows spending activities according to CMP and cost centers. According to public market law, expenditures are elaborated by grouping the suppliers per family using the CMP corresponding to each committed order [52 - 55]. Dashboards are the essential tool for allowing biomedical policy, its indicators help to measure progress in performance and to undertake actions to optimize the biomedical function. Powerful tools such as Business Objects are used to drive biomedical activity. Structured Query Language (SQL) editors in the software help to connect to databases and run queries, the universe between Business Object and the software creates dashboards models adapted to the desired biomedical policy [56, 57].

There is a set of parameters to evaluate the biomedical park such as the: i) park value ii) antiquated of each medical device iii) antiquated valorized of medical devices iv) amount of antiquated valorized, v) global antiquated of the park vi) annual drift of antiquated. The value of the biomedical park is the sum of the purchase values of each medical device. The rate of antiquated devices and the maintenance spending ratio are calculated by the formulas given in Table 6 (biomedical engineers of the Paris hospitals). The rate of antiquated is 0 if the park is new, it is 1 if all medical devices have reached their lifetime, it is greater than 1 if all medical devices have exceeded their lifetime. The rate of antiquated devices and the maintenance spending ratio were estimated for the medical specialty, biology, and imaging poles for a 500-beds hospital MSO. The rate of antiquated devices could be in the ranks from $50 \%$ to $80 \%$. Maintenance spending ratio should be in the ranks from $4 \%$ to $10 \%$. The values shown in Table 6 are estimates based on our hospital experience in engineering of medical devices (Table 6 ).

Table 6. Rate of antiquated and maintenance spending ratio.

\begin{tabular}{|c|c|c|c|c|}
\hline & Park Values & Rate of Antiquated & Maintenance Spending & Ratio \\
\hline Imaging & $10000000,00 €$ & $57,00 \%$ & $636262,00 €$ & $6,40 \%$ \\
\hline Biology & $10000000,00 €$ & $69,00 \%$ & $382009,00 €$ & $3,80 \%$ \\
\hline Medical specialty & $18000000,00 €$ & $61,00 \%$ & $595663,00 €$ & $3,30 \%$ \\
\hline Hospital & $38000000,00 €$ & $61,50 \%$ & $1613934,00 €$ & $4,20 \%$ \\
\hline
\end{tabular}

Antiquated valorized of medical device $=$ Purchase value $\times$ Antiquated Antiquated valorized biomedical park $=\sum_{i=1}^{i=n}$ Antiquated valorized of medical device 


$$
\begin{gathered}
\text { Amount of Antiquated }=\sum_{i=1}^{i=n} \text { Purchase value of medical device } \\
\text { Rate of Antiquated }=\frac{\text { Antiquated valorized biomedical park }}{\text { Amount of Antiquated valorized }} \\
\text { Ratio }=\frac{\text { Maintenance spending }}{\text { Park values }}
\end{gathered}
$$

Planned maintenance productivity must be more than $95 \%$ of priority medical devices. Improved performance indicators are achieved through the development of biomedical policy and intervention procedures. Multiple quantitative and qualitative indicators for medical devices, reactivity measurement, and risk assessment method. The data for these indicators are variables that describe the various situations of the biomedical park and note the results of its performance for the hospital. The data of the performance measurement are correlated with many variables, their interpretation depends on the biomedical park situations. The dashboard is the synthesis tool of the situations through indicators. The dashboard is the tool for monitoring medical devices engineering (Table 7).

Table 7. Dashboard of biomedical park.

\begin{tabular}{|c|c|c|}
\hline Assessment & Indicators \\
\hline Medical device & $\begin{array}{c}\text { Value of the biomedical park. ROC: evaluates the ability of hospital to use its funds for the investment to be profitable. Number of } \\
\text { medical device. Medical device under warranty. Reliability: expresses medical device's ability to perform its function for a time } \\
\text { period. Availability: means the ability of medical device to be operational at a data time }\end{array}$ \\
\hline Risk & $\begin{array}{c}\text { FMECA: determines the causes and effects of malfunctions, hierarchical criticalities and treats failure. PRA: identifies the causes } \\
\text { and effects of risks, prioritizes criticalities and treats risks. Security: indicates the ability of a medical device not to develop critical } \\
\text { incidents }\end{array}$ \\
\hline Maintenance & $\begin{array}{c}\text { Number of technical interventions and number of requests for intervention. Maintainability: reflecting the ability of medical device } \\
\text { to be maintained in a data time. TPM: ensures the maintenance while maximizing production and involving all actors in the system. } \\
\text { FRC: frequency of medical device failures in a data time. KPI: assessment of maintenance activity by measuring yield failures, } \\
\text { downtime, time availability and maintainability. Productivity of programmed maintenance. Maintenance cost ratio }\end{array}$ \\
\hline Reactivity & $\begin{array}{c}\text { Realization rate of scheduled maintenance. Status of maintenance requests (fact, not fact, fact partially, fact in shared maintenance). } \\
\text { MTTF: mean operating time of medical device until it fails. MTBF: mean time between two consecutive failures of medical device. } \\
\text { MTTR: mean time to repair and commissioning of medical device }\end{array}$ \\
\hline
\end{tabular}

\footnotetext{
Productivity of programmed maintenance $=\frac{\text { duration of realization proceedings }}{\text { theoretical duration of realization proceedings }}$

ROC $=\frac{\text { initial value of investment }}{\text { interest on the investment }}$

interest on the investment $\quad$ criticality $=$ failure probability $\times$ failure severity
}

Maintenance cost ratio $=\frac{\text { total annual of maintenance cost }}{\text { cost of purchasing medical device }}$

CMMS is the synthesis tool for all biomedical activities. The maintenance organization cannot be realized without the CMMS. It is the tool used by the hospital for engineering the medical device's inventory, the stock of spare parts, data entry, service orders, programming maintenance, history of interventions performed during the medical device lifetime, reports of interventions and tracking expenses. It helps to reduce the medical devices downtime. It is a source of information for monitoring the frequency of failures and interventions. It programs the prioritization of service orders, optimizes the time of realization of interventions, and improves the performances of maintenance. For quality assurance approach, it helps to make appropriate arrangements for the management of medical device data sheets, maintenance manuals recommended by the manufacturer then Quality and Maintenance Security Register [58 - 61].

\section{CONCLUSION}

Medical devices provide diagnosis, monitoring, and medico-surgical treatment. They have a central role in the organization and operation of the hospital for better patient care. Medical devices reduce the duration of hospitalization and the duration of the medico-surgical intervention. Biomedical engineering is an essential component of the health system in hospitals. It ensures the internal and external reports of the hospital and then the interface between physicians and medical devices. Depending on the budget allocated, the biomedical engineer programs acquisition and 
maintenance of medical devices. The decision to launch an investment for medical devices is based on multi-criteria prioritization. The dashboard is a set of indicators enabling the evaluation of hospitals' resources. The information system processes dashboard information. The information system is the synthesis tool for all medical devices engineering within the hospital.

\section{LIST OF ABBREVIATIONS}

$\begin{array}{lll}\text { AP-HP } & = & \text { Assistance Publique des Hôpitaux de Paris } \\ \text { CE } & = & \text { European conformity } \\ \text { CMMS } & = & \text { Computerized Maintenance Management System } \\ \text { ECG } & = & \text { Electrocardiogram } \\ \text { FMECA } & = & \text { Failure Mode, Effect and Criticality Analysis } \\ \text { FRC } & = & \text { Key Performance Indicators } \\ \text { KPI } & = & \text { Hospital of Medicine, Surgery and Obstetrics } \\ \text { Hospital MSO } & = & \text { International Organization for Standardization } \\ \text { ISO } & = & \text { Mean Time Between Failure } \\ \text { MTBF } & = & \text { Mean Time to Failure } \\ \text { MTTF } & = & \text { Mean Time to Repair } \\ \text { MTTR } & = & \text { Medicalization of information systems programs } \\ \text { PMSI } & = & \text { Preliminary risk analysis } \\ \text { PRA } & = & \text { Return On Capital } \\ \text { ROC } & = & \text { Structured Query Language } \\ \text { SQL } & = & \text { Total Productive Maintenance } \\ \text { TPM } & & \end{array}$

\section{CONSENT FOR PUBLICATION}

Not applicable.

\section{CONFLICT OF INTEREST}

The authors declare no conflict of interest, financial or otherwise.

\section{ACKNOWLEDGEMENTS}

We thank Marie-Hélène Maës and Monique Abuaf. We thank Roland ABUAF, PhD to have participated in the rereading of this article. This work was supported by Association Recherche et Développement Biomédical.

\section{REFERENCES}

[1] Fleming J, Iyer RM, Shortis M, Vuthaluru H, Xing K, Moulton B. Biomedical engineering curricula: Trends in Australia and abroad. World Transactions on Engineering and Technology Education 2012; 10: 23-8.

[2] Chateau Naulet PD, Viard H, Farges G. Analyse de pratiques biomédicales à l'étranger: les prémices d'un réseau biomédical hospitalier international. ITBM-RBM News 2005; 26: 22-4. [http://dx.doi.org/10.1016/S1297-9570(05)80031-7]

[3] Chien CH, Huang YY, Chong FC. A framework of medical equipment management system for in-house clinical engineering department. Conf Proc IEEE Eng Med Biol Soc 2010; 2010: 6054-7. [PMID: 21097122]

[4] Zoghlami N, Hammadi S. Conception and development of a health care risk management system. International Conference on Biomedical Engineering and Technology IPCBEE. 132-6.

[5] Wang B, Eliason RW, Richards SM, Hertzler LW, Moorey R. Financial impact of medical technology. IEEE Eng Med Biol Mag 2008; 27: $80-5$.

[http://dx.doi.org/10.1109/MEMB.2008.921548] [PMID: 18463023]

[6] Dyro JF. Clinical Engineering Handbook. Burlington, MA: Elsevier Academic Press 2004.

[7] Temple-Bird C. How to organize the maintenance of your healthcare technology. St. Albans: Teaching-aids At Low Cost 2005.

[8] Mutia D, Kihiu J, Maranga S. Maintenance management of medical equipment in hospitals. Ind Eng Lett 2012; 2: 9-19. 
[9] Ayraud I, Vaillant C, Collard C, Duval E, Petit A. Reflexions on the organisation of the purchase of single use supplies associated to biomedical equipments: Respective roles of the biomedical service and pharmacy. ITBM-RBM 2004; $25: 340-5$. [http://dx.doi.org/10.1016/j.rbmret.2004.10.007]

[10] Salgues E, Viguier JM. Sharing medical equipment in public/private partnerships. ITBM-RBM 2000; $21: 105-12$. [http://dx.doi.org/10.1016/S1297-9562(00)90013-5]

[11] Petit A, Pommier M. Maintenance et contrôles. RBMNews 1998; 20: 18

[12] Bahi A, Bonneton V, Cauffy-Akissi ME, Gautier H, Farges G. Guide des bonnes pratiques biomédicales version 2: compatibilité, progressivité et simplicité. IRBM News 2010; 31: 5-10. [http://dx.doi.org/10.1016/j.irbmnw.2010.03.002]

[13] Bedos L, Junqua R, Roudet JC, Farges G. Réflexions sur une nouvelle structure du guide des bonnes pratiques biomédicales en établissement de santé. IRBM News 2008; 29: 3-6. [http://dx.doi.org/10.1016/S1959-7568(08)75562-7]

[14] De Frondat F, Delahaye V, Gomez PJ, Podlunsek C, Farges G, Caliste JP. Laboratoires d'analyses de biologie médicale: Un outil d'autodiagnostic basé sur la norme NF EN ISO 15189. IRBM News 2010; 31: 3-6.

[15] Pommier M. La démarche qualité (IS0 9002): application à un service biomédical (3e partie). ITBM-REM 2000; $21: 45-57$. [http://dx.doi.org/10.1016/S1297-9562(00)90023-8]

[16] Walraeve B. Ingénieur biomédical à la Direction Régionale des Affaires Sanitaires et Sociales (DRASS). ITBM-RBM News 2005; 26: 3-5. [http://dx.doi.org/10.1016/S1297-9570(05)80041-X]

[17] Petay T, Pommier M, Bouhier I, Petit A. Maintenance préventive des défibrillateurs. ITBM-RBM News 2000; $21: 17-9$. [http://dx.doi.org/10.1016/S1297-9570(00)90026-8]

[18] Van Den Brande A. Maintenance biomédicale: Certification « ISO 9000 » ou accréditation hospitalière? IRBM News 2008; $29: 10-5$. [http://dx.doi.org/10.1016/S1959-7568(08)75473-7]

[19] Manuel de certification des établissements de santé. Saint Denis: HAS 2009.

[20] Introduction à la gestion du parc des équipements médicaux. Genève: OMS 2012.

[21] Fennigkoh L, Smith B. Clinical equipment management. JCAHO Plant Technology and Safety Management 1989; 2: 5-14.

[22] Wang B, Levenson A. Equipment inclusion criteria - A new interpretation of JCAHO’s Medical Equipment Management Standard. J Clin Eng 2000; 25: 26-35 [http://dx.doi.org/10.1097/00004669-200025010-00009]

[23] Constancias S, Fabrega D. Medical equipment program: The exemple of Edouard Herriot hospital. ITBM-RBM 2006; 27: 250-6. [http://dx.doi.org/10.1016/j.rbmret.2006.09.002]

[24] Kawohl W, Temple-Bird C, Lenel A, Kaur M. How to manage the finances of your healthcare technology management teams. St. Albans, Hertfordshire, UK: Ziken International 2005

[25] Évaluation des besoins en dispositifs médicaux. Genève: OMS 2012

[26] Deguenon AK. Elaboration d'une politique nationale de maintenance des dispositifs médicaux. L'exemple du Bénin. ITBM-RBM 2002; 23: $55-9$.

[http://dx.doi.org/10.1016/S1297-9562(02)80008-0]

[27] Fabrega D, Decouvelaere M, Garito R. Hospital strategy and technical means: The example of the Édouard Herriot Hospital. ITBM-RBM 2004; 25: 54-9. [http://dx.doi.org/10.1016/j.rbmret.2003.09.003]

[28] Guide de la réglementation et des recommandations relatives à la construction et au fonctionnement technique des établissements. Paris: MAINH et DHOS 2005 .

[29] Farges G, Aguida S, Ricaud L, et al. Gestion des équipements biomédicaux, selon le référentiel HAS v2010: impacts et outil d'autodiagnostic. IRBM News 2009; 30: 3-7. [http://dx.doi.org/10.1016/j.irbmnw.2009.10.002]

[30] Cohen T. AAMI's Benchmarking solution: analysis of cost of service ratio and other metrics. Biomed Instrum Technol 2010; $44: 346-9$.

[31] Perrin JP, Lifchitz H, Lajonchere JP. Prevert: un outil d'évaluation des plans d'équipement des hopitaux de 1'AP-HP. ITBM-RBM 2003; 24: $150-9$.

[http://dx.doi.org/10.1016/S1297-9562(03)00025-1]

[32] Marguet PO, Armoiry X. Le financement des dispositifs médicaux innovants. IRBM News 2012; 33: 21-30. [http://dx.doi.org/10.1016/j.irbmnw.2012.02.004]

[33] Ivon JL, Marguet PO. De la nécessité d'une politique organisée de la maintenance biomédicale. Choix d'un indicateur: Le CMA. ITBMRBMNews 2006; 27: 19-22.

[34] Jamshidi A, Rahimi SA, Ait-kadi D, Bartolome AR. Medical devices inspection and maintenance; A literature review. IIE Annual Conference Proceedings 2014; 2014: 3895-3904 
[35] Alhassane M, Nogier C, Assane A, Page M, Langevin F. About the responsibility of the medical device maintenance in French-speaking subSaharan Africa. ITBM-RBM 2003; 24: 223-30. [http://dx.doi.org/10.1016/S1297-9562(03)00044-5]

[36] Georgin D, Natan J, Szymczak H, Farges G. Management de l'externalisation de la maintenance biomedicale. ITBM-RBM News 2005; 26: $7-11$. [http://dx.doi.org/10.1016/S1297-9570(05)80042-1]

[37] Ogembo-Kachieng'a M, Ogara WO. Strategic management of technology in public health sector in Kenya and South Africa. East Afr Med J 2004; 81(6): 279-86. [http://dx.doi.org/10.4314/eamj.v81i6.9176] [PMID: 16167674]

[38] Programme de maintenance des équipements médicaux: présentation générale. Genève: OMS 2012.

[39] Houria ZB, Masmoudi M, Al Hanbali A, Khatrouch I, Masmoudi F. Quantitative techniques for medical equipment maintenance management. Eur J Ind Eng 2016; 10: 703-23. [http://dx.doi.org/10.1504/EJIE.2016.081017]

[40] Ridgway M. Classifying medical devices according to their maintenance sensitivity: A practical, risk-based approach to PM program management. Biomed Instrum Technol 2001; 35(3): 167-76. [PMID: 11395976]

[41] Miniati R, Dori F, Iadanza E, Fregonara Medici M. A New Failure Analysis for Maintenance Management in Complex Hospitals. IJECE 2008; 2: 1604-6.

[42] Rishel TD, Canel C. Using a maintenance contribution model to predict the impact of maintenance on profitability. Journal of Information \& Optimisation Sciences 2006; 27: 21-34. [http://dx.doi.org/10.1080/02522667.2006.10699676]

[43] Haddad TH, Jaaron AAM. The Applicability of Total Productive Maintenance for Healthcare Facilities: An Implementation Methodology. International Journal of Business. Hum Technol 2012; 2: 148-55.

[44] Contandriopoulos AP, Souteyrand Y. L'hôpital stratège: Dynamiques locales et offre de soins. Paris: John Libbey Eurotext 1996.

[45] Claveranne JP. Le management par projet à l'hôpital. Revue Française de Gestion 1996; 109: 103-13.

[46] Garrot T. La gestion hospitalière par la méthode ABC. Revue Française de comptabilité 1995; $273:$ 53-61.

[47] Valette A. Une gestion stratégique à l’hôpital ?. Revue Française de Gestion 1996; 109: 92-99.

[48] King M, Lapsley I, Mitchell F, Moyes J. Costing Needs and Practices in a Changing Environment: The Potential for ABC in the NHS. Financ Account Manag 1994; 10: 143-60. [http://dx.doi.org/10.1111/j.1468-0408.1994.tb00150.x]

[49] Pettersen IJ. Budgetary control of hospitals- ritual rhetorics and rationalized myths? Financ Account Manag 1995; 11: 207-21. [http://dx.doi.org/10.1111/j.1468-0408.1995.tb00170.x]

[50] Masse MC. Le contrôle de gestion dans un hôpital public: Un modèle de transactions diagonales. Comptabilité Contrôle Audit 1996; 1: 21-43. [http://dx.doi.org/10.3917/cca.021.0021]

[51] Ben Maiz S, Egarnes L, Neyret C, Farges G. Optimisation du choix des référentiels de qualité et de maintenance. IRBM News 2007; 28: 11-4. [http://dx.doi.org/10.1016/S1959-7568(07)80595-5]

[52] Le Manac'h Y, Decouvelaere M, Durand-Gasseli F. Méthodologie de programmation des investissements biomédicaux. ITBM-RBM 2004; 25: 113-24. [http://dx.doi.org/10.1016/j.rbmret.2004.02.006]

[53] Rocha LS, Bassani JWM. Cost management of medical equipment maintenance. Conf Proc IEEE Eng Med Biol Soc 2004; 5: 3508-11. [PMID: 17271045]

[54] Auffret V, Grégoire JM. Purchase and quality: appraising, selection and control of the subcontracters. ITBM-RBM 2000; $21: 58-62$. [http://dx.doi.org/10.1016/S1297-9562(00)90024-X]

[55] Vigneron B, Taillard JF. Gestion et automatisation sur tableur du suivi des achats d'équipements classés par code nomenclature. IRBM News 2009; 30: 10-5. [http://dx.doi.org/10.1016/S1959-7568(09)72355-7]

[56] Soncini' E, Petit A. Risks management and maintenance choices at the hospital. ITBM-RBM 2002; 23: 172-9.

[57] Pons S, Petit A, Carbonel V, Pierrefitte S. Risk and management approach applied to medical equipment purchasing department. ITBM-RBM 2005; 26: 163-9.

[http://dx.doi.org/10.1016/j.rbmret.2004.10.005]

[58] Saharkhiz E, Bagherpour M, Feylizadeh MR, Afsari A. Software Performance Evaluation of a Computerized Maintenance Management System: A Statistical Based Comparison Eksploatacja i Niezawodnosc - Maintenance and Reliability 2012; 14: 77-83.

[59] Imbaud C. Les pratiques biomédicales hospitalières en Allemagnes, l'exemple du CHU de Hambourg. IRBM News 2008; 29 : 12-26. [http://dx.doi.org/10.1016/S1959-7568(08)75565-2] 
[60] Fouad RH, Rawashdeh M. AL-Bashir A, AL-Sharif B. Designing a computerized maintenance management system for medical devices in royal medical services. IJRRAS 2012; 10: 115-8

[61] Taghipour S, Banjevic D, Jardine AKS. Prioritization of medical equipment for maintenance decisions. J Oper Res Soc 2011 ; 62: 1666-87. [http://dx.doi.org/10.1057/jors.2010.106]

\section{(C) 2018 Moumaris et al.}

This is an open access article distributed under the terms of the Creative Commons Attribution 4.0 International Public License (CC-BY 4.0), a copy of which is available at: (https:/creativecommons.org/licenses/by/4.0/legalcode). This license permits unrestricted use, distribution, and reproduction in any medium, provided the original author and source are credited. 